\title{
Government Intervention in the Education Sector and the Consequences of the Privatisation of Education
}

\author{
Ameya Sathya Kakade*
}

\section{Introduction:}

Imagine a country where the children have to pay to learn; Imagine a country where schools regard profit above a student's future; Imagine a country where the people do not have a voice in what their child learns, where without government intervention the education sector has been engulfed in the doom of profit.

Education policy has been at the forefront of discussions that relate to the economic prosperity of various nations. But, there still seems to be a sense of unclarity in the ongoing debate on whether the education sector needs to be privatised or still conform to the mixed economic model that lays as the fundamental nucleus of most countries' education policies. Should India and the United States continue to spend their 3.1\% ${ }^{1}$ and $6.2 \%$ of their GDP respectively on the education sector? Or would education be buoyant under privatisation?

Whilst this article hopes to put forth the various arguments that are prevalent today and complement this discussion with the Indian education model, as a case study, it also looks to answer the question - how would the education sector change if governments were no longer involved?

\section{The Interconnection between Education and the Economy:}

It is widely accepted that education correlates with an advancement in a country's labour force and strengthens a nation's economic prosperity. With the education policy acting as a longterm measure to increase the productive capacity of the economy, causing an outward shift in the country's Production Possibility Curve, there is little reservation into the impact that a strong and well-designed education policy can have in determining the economic future of a nation's workforce and economy. This section will look to analyse the reliance of a country on its education system to put forward a context for the discussion on the potential advantages and shortcomings of the market- and mixed-economic models.

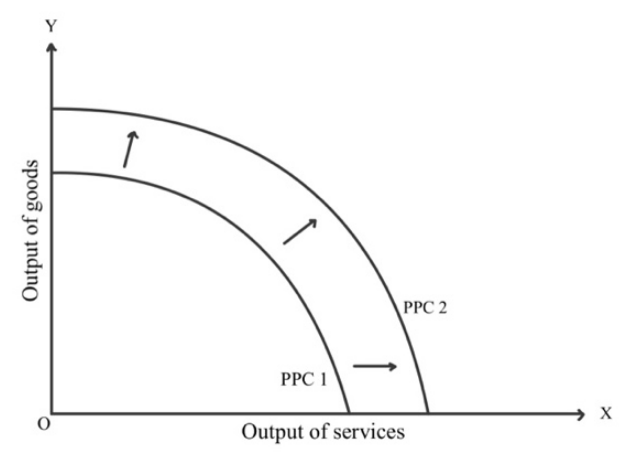

Figure 1: Outward Shift in the Production Possibility Curve

\footnotetext{
* The International School Bangalore, Bangalore, India

${ }^{1}$ Schroll.in; Explainer: Why Budget 2021 is crucial for public school education in India;

https://scroll.in/article/985125/explainer-why-budget-2021-is-crucial-for-public-school-education-in-india
} 
The past decade has brought with it rapid globalisation of world economies, where countries are striving to become increasingly interdependent and interconnected. Whilst this has led to an increase in trade and economic growth, globalisation has also made many nations to regard education as human investment, which may be realised on micro and macroeconomic levels as investment made by a person on himself (micro-level), or the investment made by the state on its citizens (macro-level). ${ }^{2}$ One of the safest investments that a country can make today, which could potentially thrust it higher upon the world economic arena, is an investment in its education sector. At the micro-level, the return on education is categorised as the calculation of individual and social returns of definite education levels and occupations. ${ }^{3}$ The figure provided by Michaelowa ${ }^{4}$ below, further highlights the expected returns of education on both the Micro- and Macro-economic levels.

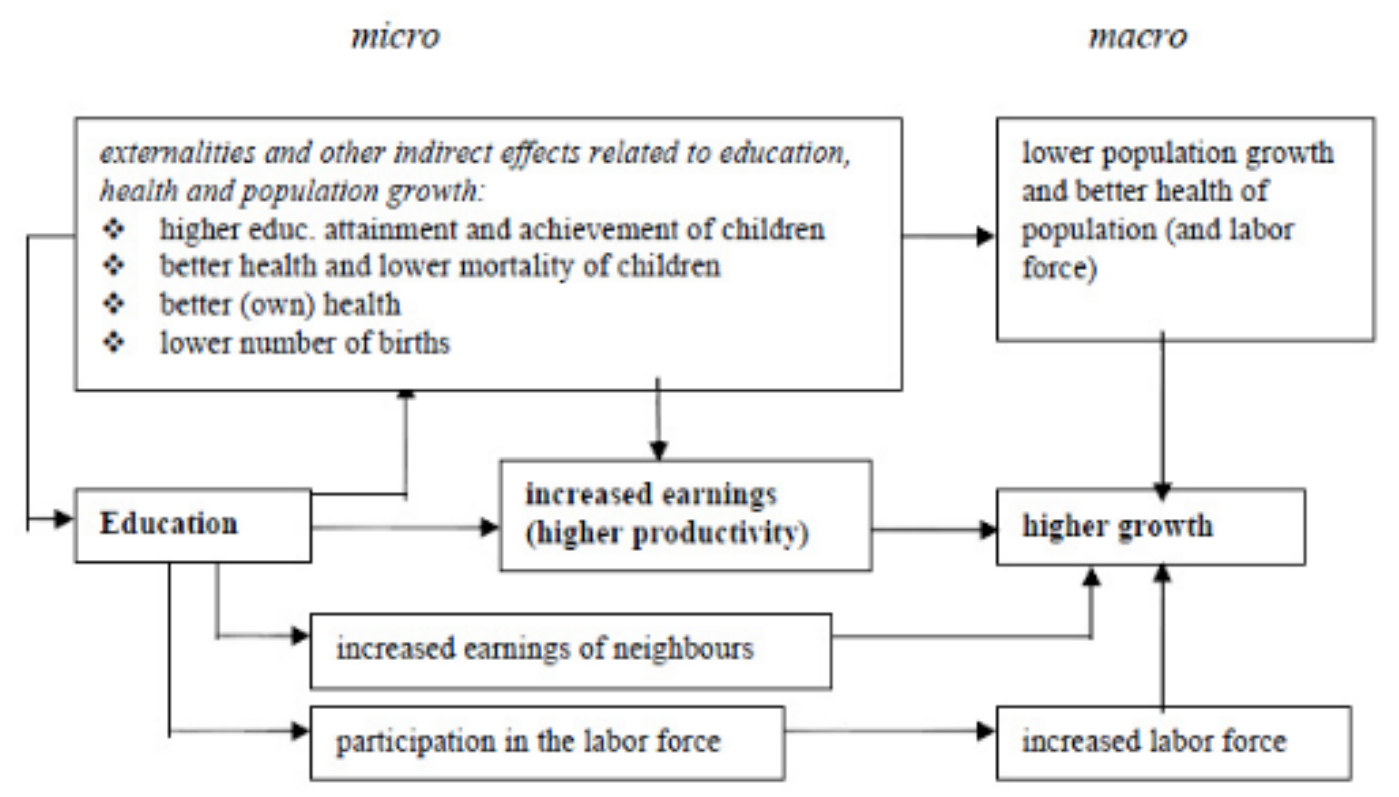

Figure 2: The Returns of Education, Michaelowa, 2000 p.2.

As seen by the figure above, Education directly complements an increase in the country's labour force participation rate and is a direct determinant of an increase in the labour productivity. Moreover, investment in education also supplements better standards of living and healthcare at a micro level, as evidenced by the lower mortality rate in children and better general health of a country's citizens. Furthermore, from a macro and socio-economic standpoint, education reduces the population growth and increases the productivity of the labour force.

\footnotetext{
${ }^{2}$ Mehtap, T. U. N. Ç. (1998). KALKINMADA İNSAN SERMAYESİ: İÇ GETİRİ ORANI YAKLAŞIMI VE TÜRKIYE UYGULAMASI. Dokuz Eylül Üniversitesi İktisadi İdari Bilimler Fakültesi Dergisi, 13(1), 83-93.

${ }^{3}$ Ozsoy, C. and Sürmeli A., (2012), “Eitim Yatrmlarnn Getirisi: Anadolu Üniversitesinin Sosyal Bilimler Alannda Eitim
Veren Fakülte Mezunlarna Yönelik Bir Aratrma”, Anadolu Üniversitesi Sosyal Bilimler Dergisi, Cilt:12, Say:2.

${ }^{4}$ Michaelowa, K., (2000), Returns to Education in Low Income Countries: Evidence for Africa, Committee on Developing Countries of the German
} 
Additionally, education sets itself as a key factor in the reasons for differences in earnings of workers. In general, skilled workers earn more than unskilled workers due to their relatively high demand and low supply. Skilled professions that require a university degree, will tend to be inelastic in supply, as compared to those professions which require no threshold for education.

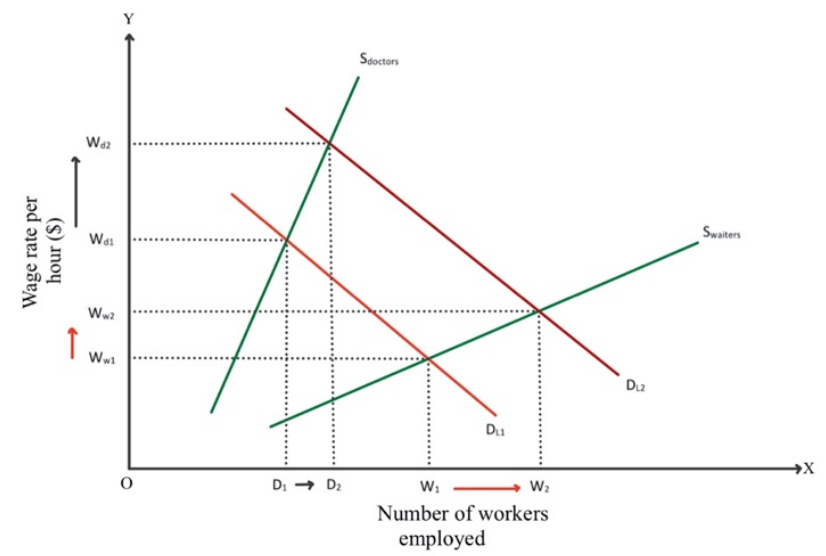

Figure 3: The difference in the equilibrium wage rates of waiters and doctors

As seen by the Figure 3 above, the demand and supply of waiters (unskilled profession) and doctors (skilled profession) is displayed. Waiters are portrayed to be elastic in supply ( $\left.\mathrm{S}_{\text {waiters }}\right)$, as with an increase in demand from $\mathrm{D}_{\mathrm{L} 1}$ to $\mathrm{D}_{\mathrm{L} 2}$, the percentage change in quantity of waiters supplied ( $\mathrm{W}_{1}$ to $\left.\mathrm{W}_{2}\right)$, will be greater than the percentage increase in wages $\left(\mathrm{W}_{\mathrm{w} 1}\right.$ to $\left.\mathrm{W}_{\mathrm{w} 2}\right)$, as indicated by the red arrows. As education is said to play an important role in improving a country's GDP per Capita in the future, it is therefore discernible that not only providing education, but quality education is the need of the hour.

Education also holds significance from a socio-economic perspective of an economy. This is one of the reasons why, whilst measuring the economic development, which also encapsulates improvements in the social aspects of the country, education is taken as a key dimension. For example, the Human Development Index, a composite indicator of living standards in the country, also considers Education to be a dimension of human development, acting as a strong recommender for the economic development of a nation.

\begin{tabular}{|c|c|c|c|c|c|c|}
\hline Rank & Country & $\begin{array}{l}\text { HDI } \\
\text { Value } \\
(2019)\end{array}$ & $\begin{array}{l}\text { Life } \\
\text { Expectancy } \\
\text { at Birth } \\
\text { (years) }\end{array}$ & $\begin{array}{l}\text { Expected } \\
\text { Years of } \\
\text { Schooling } \\
\text { (year) }\end{array}$ & $\begin{array}{l}\text { Mean } \\
\text { Years of } \\
\text { Schooling } \\
\text { (years) }\end{array}$ & $\begin{array}{l}\text { Gross } \\
\text { National } \\
\text { Income } \\
\text { (GNI) per } \\
\text { capita } \\
\text { (PPP \$) }\end{array}$ \\
\hline 1 & Norway & 0.957 & 82.4 & 18.1 & 12.9 & 66,494 \\
\hline 2 & Ireland & 0.955 & 82.3 & 18.7 & 12.7 & 68,371 \\
\hline 2 & Switzerland & 0.955 & 83.8 & 16.3 & 13.4 & 69,394 \\
\hline 188 & $\begin{array}{l}\text { Central } \\
\text { African } \\
\text { Republic }\end{array}$ & 0.397 & 53.3 & 7.6 & 4.3 & 993 \\
\hline 189 & Niger & 0.394 & 62.4 & 6.5 & 2.1 & 1,201 \\
\hline
\end{tabular}

Table 1: Human Development Index Ranking 2020.

Source: UNDP Human Development Report 
Table 1 compares the data from the top three countries and the bottom two countries in the Human Development Index Ranking 2020.5 As seen in the table above, it is evident that countries that record a higher Expected and Mean Years of Schooling are shown to exhibit higher Gross National Income. Similarly, students in countries like the Central African Republic are shown to be educated for an average of only 4.3 years, accounting to 8.6-year deficit in Education, when compared with students in Norway. Calculating the difference in Income per Capita, this accounts to a loss of about $\$ 70,413.5^{6}$ per year as potential income.

It is therefore evident, that there exists a strong correlation between Education and Economic Development.

Looking at education's significance in determining the future of a country, government intervention is crucial in the education sector.

\section{How would the education sector change if governments were no longer involved and the sector adopts a market economic model?}

Having considered the benefits of education from both an economic and social standpoint of a nation, countries must look to enforce an education policy that has the potential to foster learning amongst its students. However, the debate arises on whether a country must privatise its education sector, or implement a mixed economic model, where the government retains a substantial market share to administer regulations and oversight.

A market economic model would rely on the market forces of demand and supply in the private sector to allocate resources with minimal government intervention. However, the drive for profit that private educational institutions would have, could lead to discrimination in who attains education, and would in turn reduce the accessibility of education to a country's citizens. This would lead to a violation of the basic fundamental right to education that is entrusted to each citizen. This stands as one of the main reasons why almost all the nations in the world retain government intervention in the education sector.

In some cases, privatisation of education could hinder the government's efforts to achieve its macroeconomic aims - especially those of reducing inequalities in income and wealth, low unemployment, and economic growth. There is no doubt, that if a country was to follow a market economic model for education, the poorer sections of the society would be neglected. Students who would come from more privileged backgrounds would have a larger choice, with a higher level of economic freedom, where the model would stive to meet their requirements. Education a merit good. If society is left to decide whether to adopt it or not, it may be under consumed. An opportunity cost would arise to lesser privileged children, who would tend to choose income over education, as private schools would require their families to have a substantial household income. This is a pragmatic viewpoint of how the education sector will look like and change if there is no government involvement.

However, there are also certain aspects of privatisation that must be looked at, whilst considering whether governments should be involved in the education sector. Looking at the Indian Education system, the government offers free educational services through government-

\footnotetext{
${ }^{5}$ United Nations Development Programme, Human Development Reports, http://hdr.undp.org/en/content/latest-humandevelopment-index-ranking

${ }^{6}[(66494 \times 8.6)-(993 \times 8.6)] / 8=\$ 70,413.5$
} 
run schools for under-privileged students. However, the mental model ${ }^{7}$ that is retained by Indian citizens, regardless of economic background, is that private schools provide their children with better opportunities and access to education services. (Desai et al. 2008) ${ }^{8}$ examines the following assumption.

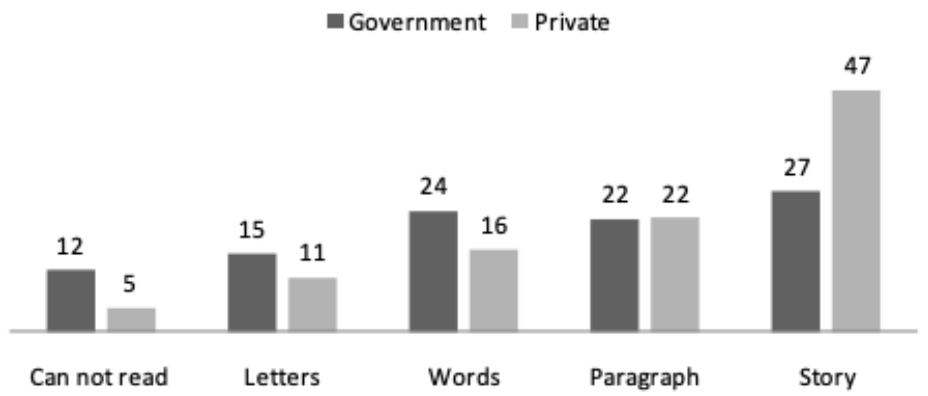

Figure 4: Distribution of Reading Skill by School Type ${ }^{7}$

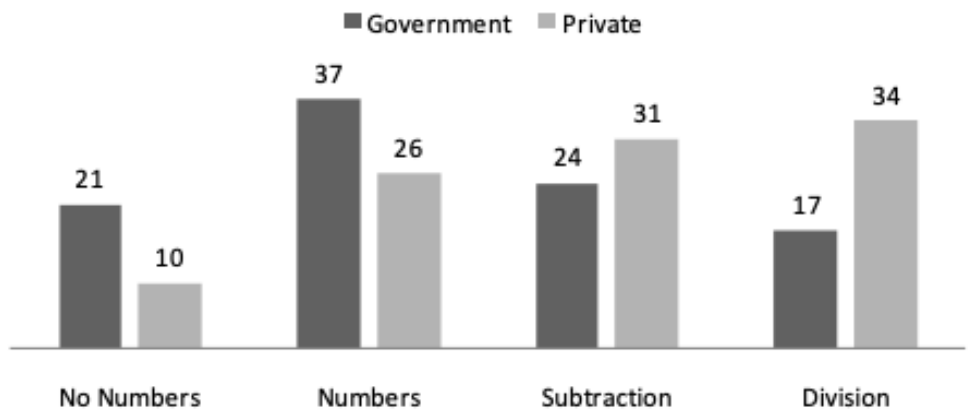

Figure 5: Distribution of Arithmetic Skills by School Type ${ }^{7}$

As seen by Figure 4 and Figure 5 above, the distribution of Reading and Arithmetic Skills by school type is largely similar, with, in fact, private schools performing worse than government schools in some cases. For example, private schools fare almost $30 \%$ worse when comparing whether their students have knowledge of Numbers. Furthermore, (Desai et al. 2008) ${ }^{7}$ also records that almost $85.9 \%$ of teachers in government schools, as compared to the $43.8 \%$ in private schools, are trained in their respective subjects. Then, the question arises, why is there a strong drive for a reduction in government intervention when governments strive to ensure unrestricted access to a public and merit good such as education?

Regardless of whether we try to implement the market economic model or not, educational services are regarded as a public good. Being non-excludable allows each and every person to reap its benefits even without paying, whilst being non-rivalrous increases the mixed economic model's dependence on government expenditure to fund its services. However, this is one of the key reasons why education policy can be regarded as a form of market failure, where despite being a social benefit, education is under consumed. Considered as a merit good, which when

\footnotetext{
${ }^{7}$ A mental model is an explanation of someone's thought process about how something works in the real world. It is a representation of the surrounding world, the relationships between its various parts and a person's intuitive perception about his or her own acts and their consequences.

${ }^{8}$ Desai, S., Dubey, A., Vanneman, R., \& Banerji, R. (2008, June). Private schooling in India: A new educational landscape. In India Policy Forum (Vol. 5, No. 1, pp. 1-58). Global Economy and Development Program, The Brookings Institution.
} 
consumed can create positive spill over effects in the economy, the educational model must be refined to retain government intervention.

Firstly, maintaining a mixed economic model for education could be regarded as a purposeful decision. Not only can the citizens of a country enjoy a greater efficiency in the education sector, but the privatisation of education can also reduce the costs to tax payers. To complement and fasten the economic model further, governments can subsidise the private sector, which could act as a stimulus in countries like India, for more children to pursue education. Coupled with the direct provision of education from the government, economies can ensure that the service is not under-consumed and accessible. Furthermore, government intervention to enforce mandatory schooling and to decide on the broad outline of the content and nature of the education provided would be beneficial to the society ${ }^{9}$. Governments can also provide skillbased training to improve the pedagogy in schools, which would act as a method to continually improve a nation's education services.

Education is a key catalyst for the empowerment of a country's citizens and can be regarded as a social benefit. Not only would an educated workforce help a country's citizens on an individual level, but will also bring with it external benefits, that could impact the society as a whole. Education is one such aspect that the private sector must not exploit for a profit motive, and a country must retain government intervention that would act as an anchor to preserve human development from the pessimistic nuances of privatisation.

\section{Bibliography:}

Desai, S., Dubey, A., Vanneman, R., \& Banerji, R. (2008, June). Private schooling in India: A new educational landscape. In India Policy Forum (Vol. 5, No. 1, pp. 1-58). Global Economy and Development Program, The Brookings Institution.

Mehtap, T. U. N. Ç. (1998). KALKINMADA INSAN SERMAYESI: IÇ GETIRII ORANI YAKLAŞIMI VE TÜRKIYY UYGULAMASI. Dokuz Eylül Üniversitesi İktisadi İdari Bilimler Fakültesi Dergisi, 13(1), 83-93.

Michaelowa, K., (2000), Returns to Education in Low Income Countries: Evidence for Africa, Committee on Developing Countries of the German

Ozsoy, C. and Sürmeli A., (2012), "Eitim Yatrmlarnn Getirisi: Anadolu Üniversitesinin Sosyal Bilimler Alannda Eitim Veren Fakülte Mezunlarna Yönelik Bir Aratrma”, Anadolu Üniversitesi Sosyal Bilimler Dergisi, Cilt:12, Say:2.

Santhakumar, V. (2018). The Need to Strengthen Government Schools in India. Practice.

Schroll.in; Explainer: Why Budget 2021 is crucial for public school education in India; https://scroll.in/article/985125/explainer-why-budget-2021-is-crucial-for-public-school-education-in-india

United Nations Development Programme, Human Development Reports, http://hdr.undp.org/en/content/latesthuman-development-index-ranking

\footnotetext{
${ }^{9}$ Santhakumar, V. (2018). The Need to Strengthen Government Schools in India. Practice.
} 